\title{
Eğitim Örgütlerinde Pozitif Psikolojik Sermaye, Birey- Örgüt Uyumu ve Örgütsel Yabancılaşma Arasındaki İlişki ${ }^{1}$
}

\author{
İlknur ŞENTÜRK* Gülcan SEÇİLMIŞ⿻゙*
}

ÖZET

Bu çalışmanın amac1; öğretmenlerin örgütsel yabancılaşma, birey-örgüt uyumu ve pozitif psikolojik sermaye alg1 düzeylerin tespit etmek, bu değişkenler arasındaki ilişkiyi saptamak ve araştırmanın sonuçlarına göre örgütsel yabancılaşma sorununa ilişkin çözüm önerileri getirmektir. Bu amaç doğrultusunda öğretmenlerin örgütsel yabancılaşma, birey-örgüt uyumu ile pozitif psikolojik sermaye algıları arasındaki yapısal ilişkileri açıklayan bir model oluşturulmuş ve modeli test etmek için Eskişehir Tepebaşı ilçesi devlet okullarında görev yapan 456 öğretmenden anket yoluyla veriler toplanmıştır. Araştırma sonucunda pozitif psikolojik sermaye alt boyutları ile birey-örgüt uyumunun, örgütsel yabancılaşmayı etkileyen anlamlı bir etken olduğu belirlenmiştir. Ayrıca birey-örgüt uyumunun pozitif psikolojik sermaye ile yabancılaşma arasında aracılık etkisi de saptanmıştır. Öğretmenlerin örgüte uyumlarının sağlanması ve öz yeterlilik algılarının yükseltilmesi ile davranış değişikliklerin ortaya çıkacağı ve yabancılaşmanın azalacağı sonucuna ulaşılmıştır. Öğretmenlerin psikolojik sermaye algıları arasında en düşük katılım puanı alan boyut iyimserliktir. Bu algı birçok sebepten kaynaklı olabilir. Ancak eğitim sistemindeki sorunlara yönelik iyileşmelere gidilmesi, iyimser düşünme biçimini geliştirecektir.

Araştırma Makalesi

Geliş: 05.09.2020

Kabul: 29.12.2020

Anahtar Kelimeler:

Pozitif Psikolojik

Sermaye, Birey-Örgüt

Uyumu, Örgütsel

Yabancılaşma,

Öğretmenler

\section{The Relationship Between Positive Psychological Capital Person-Organization Fit and Organizational Alienation}

\section{ABSTRACT}

The aim of this study is; to detect the organizational alienation of teachers, person-organization fit and the levels of positive psychological capital perception, to determine the relationship between these variables and to bring solution suggestions to the issue of organizational alienation related to the results of the study. For this purpose, a model has been created which describes the structural relationships between the organizational alienation of teachers, person- organization fit and positive psychological capital perceptions in Eskişehir Tepebaşı district public schools and to test the model data were collected from 456 teachers through a survey. As a result of the research, positive psychological capital sub-dimensions and person-organization fit were determined as a significant factor affecting the organizational alienation. In addition, the mediation effect of person-organization fit between positive psychological capital and alienation was also determined. It has been concluded that behavioral changes will emerge and alienation will be reduced by providing teachers' adaptation to the organization and raising their self-efficacy perceptions. The dimension that got the lowest participation score among teachers' perceptions of psychological capital is optimism. This perception can be caused by many reasons. However, making improvements to eliminate the problems in the education system will improve the optimistic way of Research Article

Received: 05.09.2020

Accepted: 29.12.2020

Keywords:

Positive Psychological capital, Person-

Organization Fit,

Organizational

Alienation, Teachers thinking.

\footnotetext{
${ }^{1}$ Bu makale, Eskişehir Osmangazi Üniversitesi, Eğitim Bilimleri Enstitüsü, Eğitim Yönetimi Ana Bilim Dalı Yüksek Lisans Programı kapsamında, Doç.Dr. İlknur Şentürk danışmanlığında yönetilmiş,"Pozitif psikolojik sermaye, birey örgüt uyumu ve örgütsel yabancılaşma arasındaki ilişki " başlıklı yüksek lisans tezinden üretilmiştir.

* Doç. Dr., Eskişehir Osmangazi Üniversitesi, Eğitim Yönetimi Anabilim Dalı, ilknurkokcu@gmail.com, ORCID ID: https://orcid.org/0000-0002-2096-614X

** Anadolu Üniversitesi, Eğitim Bilimleri Enstitüsü, Eğitim Yönetimi Doktora Öğrencisi, gulcansec@ gmail.com, ORCID ID: https://orcid.org/0000-0002-8080-6105
} 


\section{GİRIŞ}

Girdisi ve çıktısı insan olan okulları amacı, bireye gerekli bilgi beceriyi kazandırarak sağlam ve iyi karakterli insanlar yetiştirmektir. Toplumdaki huzur ve barışı sağlamak, nitelikli insan gücü yetiştirmek, toplumun kültür ve değerlerini genç nesillere aktarmak, bireyin bedenen ve zihnen gelişmesini sağlamak, bireyi duygu fikir ve inanç yönünden geliştirmek de öğretmeninin başlıca görevleri arasındadır. Öğretmenin niteliği ile yetiştirdiği öğrencinin niteliğinin özdeş olması beklenen bir durumdur. Eğitim örgütlerinde öğretmenin "insan mimarı, sanatkâr" olarak anılması öğretmenin ne derece önemli bir paydaş olduğunun altını çizmektedir. Tam da bu noktada öğretmenin pozitif dünya görüşüne sahip olması, kendine güvenmesi, zorluklar karşısında pes etmeden yoluna devam etmesi geleceğe iyimser ve umutla bakması yetiştireceği nesiller açısından son derece önemlidir. Okullar öğrencilerin, öğretmenlerin ve yöneticilerin rol aldığı açık ve sosyal bir sistemdir. Bu sistemin sağlıklı bir şekilde işlemesi için örgütün ortak değerlere sahip olması ve tüm paydaşlarının işbirliği içinde çalışması gerekmektedir (Şişman, 2002: 10). Okulun tüm paydaşlarının uyum içinde olması, verimliliği ve etkililiği beraberinde getirecektir. Okulun değerleri ve hedefleri ile bireylerin değerlerinin uyum sağlaması ve ihtiyaçların karşılıklı giderilmesi ile ortak bir sinerji oluşmakta, bireylerde psikolojik iyi oluş ve aidiyet duyguları gelişmektedir (Sığr1 ve Gürbüz, 2013: 176). Buna rağmen okullardaki bürokratik yapı, demokratik olmayan yönetim biçimi, öğretim süreçlerinin dışarıdan belirlenmesi, yoğun müfredat, günlük hayatta karşıllığ olmayan bilgilerin öğretilmeye çalışılması, ders yükü, kalabalık sınıflar gibi etkenler eğitimde yabancılaşmaya neden olmaktadır (Erjem, 2005: 397). Bu sebeple yabancılaşmanın en çok yaşandığı örgütler arasında, okullar ilk sıralardadır (Ataş ve Ayık, 2013: 106; Yapıcı, 2004: 8). Eğitim sisteminin başında gelen okulların aşırı merkeziyetçi ve bürokratik yapısı, örgüt çalışanlarını karara katılım veya inisiyatif kullanma konusunda sınırlamaktadır. Eğitim örgütlerinin en önemli çalışanı olan öğretmen, ders müfredatları, ders çizelgeleri ve yönetmelikler oluşturulurken herhangi bir katkısının olduğunu düşünmemektedir (Yılmaz ve Sarpkaya, 2009: 325). Eğitim programlarının belirlenmesi ve geliştirilmesi konusunda etkisinin olmadığını düşünen öğretmen kendisini yabancı ve güçsüz hissetmektedir. Eğitim ile ilgili kanun ve yönetmeliklerin öğretmenin özgürce hareket etmesini kısıtlaması, eğitimsel olanakların ve kaynakların yetersiz olması, emek ve çabalarının yeterince takdir edilmemesi, örgüt içindeki diğer çalışanlarla olan ilişkilerin kötüye gitmesi ve öğretmenin yalnızlık duygusu yaşaması, başarılı ve başarısız öğretmenler ayrımı yapılması öğretmenin işine yabancılaşmasına sebep olmaktadır. Yabancılaşma, öğretmenin eğitim ve öğretimle ilgili süreçlerden soğumasına, yaptığı işi anlamsız bulmasına, giderek zevksiz ve sıkıcı bir hal almasına yol açmaktadır. 
Değişimin hızla yaşandığı günümüz dünyasında örgütler varlıklarını koruyabilmek ve başarılı olabilmek için sürekli kendilerini geliştirmeye ihtiyaçları vardır. Herhangi bir örgütün başarısında etkili olan en önemli unsur ise insandır. Araştırmada söz konusu olan örgüt, eğitim örgütleri (okullar) dir. Eğitim örgütlerinin en önemli girdilerinden biri olan öğretmenler ise bu araştırmanın merkezinde yer almaktadır. Çocukların fiziksel, sosyal ve ruhsal olarak sağlıklı yetişmelerinde kritik önem taşıyan öğretmenin, öncelikle her açıdan sağlıklı bir birey olması gerekir. Bu bağlamda araştırmada öğretmenlerin psikolojik sermaye algısı ile birey-örgüt uyumu, yabancılaşma sorununu ne ölçüde etkilemekte sorusuna cevap aranarak, eğitim örgütlerinin verimliliğini ve başarısını arttıracak çözüm önerileri getirmek amaçlanmıştır. Ayrıca örgütlerde rekabet edilebilirlikte önem arz eden birey-örgüt uyumunun, okulun ve öğretmenin birbirine uyumu olarak özelleştirilerek sorunlara, özellikle yabancılaşmanın azaltılmasına ne ölçüde katkısının olduğu araştırılmaktadır. Öğretmenin değer yargıları, idealleri ve istekleri ile okulun hedefleri, değerleri ve istekleri arasında uyumu yakalamak ve sorunları çözmek adına elde edilen bulgular ile alanyazınına katkı sağlanacağı düşünülmektedir.

\section{KAVRAMSAL ÇERÇEVE}

\section{Pozitif Psikolojik Sermaye}

Sürdürülebilir rekabet için değişim ve gelişime ayak uydurmak isteyen örgütler açısından insan faktörünü ön plana çıkaran maddi/parasal kaynaklı olmayan sermaye türlerinden pozitif psikolojik sermaye geleneksel sermaye türlerine göre daha fazla rekabet üstünlüğü sağlamaktadır (Luthans ve Youssef, 2004: 145). Çalışanların eksik veya problemli taraflarına odaklanmak yerine, güçlü ve geliştirilebilir yönlerine odaklanılmasını savunan pozitif psikolojik sermaye; ekonomik sermayenin "Neye sahipsin?", insan sermayesinin "Ne biliyorsun?" ve sosyal sermayenin "Kimi tanıyorsun?" sorularının aksine bireye "Kimsin ve Ne olacaksın?" sorularını yöneltir (Luthans, Youssef ve Avolio, 2006: 388). Ayrıca, çalışanların psikolojik kaynaklarının gelişimsel durumunu ifade eden pozitif psikolojik sermaye örgütsel davranış alanındaki sorunlara alternatif bir yaklaşım önermektedir. Çünkü pozitif psikolojik sermaye, çalışanların kalıcı özellikleri yerine, örgütsel amaçları gerçekleştirmek için eğitimle ve deneyimle geliştirilebilen özelliklerini vurgulamaktadır (Luthans, Avey, Avolio ve Peterson, 2010: 43). Böylelikle pozitif bir örgüt ortamının ve pozitif örgütsel çıktıların oluşturulmasını sağlamaktadır (Büyükgöze, 2014: 19).

Pozitif psikolojik sermaye bireylerin pozitif özelliklerinden olan öz yeterlilik, umut, iyimserlik, psikolojik dayanıklılık, güven ve dışa dönüklüğün birleşiminden oluşan bir kavramdır. Bir hedefi gerçekleştirmek 
yeteneklerine güvenmesini ifade eden öz yeterlilik, bireyin en güçlü özelliklerinden biridir. (Luthans ve Youssef, 2004: 150). Bu bakımdan öz yeterlilik, bireyin bilgi ve beceri anlamında ne denli yetkin olduğu ile değil, kendi becerilerine dair ne denli inançlı olduğu ile ilgili bir kavramdır (Özkalp ve Kırel, 2009: 74). Umut, bireyin hedefine ulaşmak için gerektiğinde farklı yollar belirleyerek sebat göstermesini kapsamaktadır (Luthans, Avolio, Avey ve Norman 2007: 153). Snyder'e (1995) göre ise hedefin öneminin ve gerçekleştirilebilme olasılığının temel belirleyicisi bireyin o hedefe yönelik umut derecesidir. Dayanıklılık (psikolojik rezilyans), bireyin başarısızlık veya sorumluluğun artması gibi stres yaratan beklenmedik durumlarda dahi kendini toparlayıp yenileyebilme kapasitesidir (Keleş, 2011: 348). Dayanıklılık, Sandage ve Hill'e (2001: 250) göre kişinin hem kendisini hem de çevresini kontrol edebilmesinin bir göstergesidir. İyimserlik, kişinin kendine inanmasıyla birlikte gelecekte de başarılı olacağına ve kendisini iyi şeylerin beklediğine yönelik olumlu bakış, açısıdır (Çetin, Şeşen ve Basım, 2013: 99). Snyder ve Lopez’e (2002: 62) göre iyimserlik, kişinin kendisi için önemli olan durum ve sonuçlara ilişkin algılarını etkileyen ve yönlendiren bilişsel bir süreçtir. Güven, kişinin diğerlerine bağlanmak konusunda kuşku ve kaygı duymamasıdır. Dışa dönüklük ise kişinin bulunduğu ortama kolaylıkla uyum sağlayabilmesi, iletişim kurmakta güçlük çekmemesi ve sosyal ilişkilerde güçlü olma durumu açıklamak için kullanılmaktadır (Tösten ve Özkan, 2014: 432).

\section{Birey-Örgüt Uyumu}

Birey-örgüt uyumu, her iki tarafin da bezer temel özellikleri taşıdıkları ve bir birlerinin ihtiyaçlarını karşıladıkları zaman ortaya çıkmaktadır (Kristof, 1996: 4). Bu uyumun temelinde ise bireysel ve örgütsel değerler yatmaktadır (Kılıç, 2010: 21). Chatman'e (1989: 339) göre birey-örgüt uyumu, bireyin değerleri ile örgütün norm ve değerlerinin birbiriyle uyum sağlamasıdır. Değerler, örgütü oluşturan bireylerin davranışlarına rehberlik eden; örneğin dürüstlük, çalışkanlık, adil olma, takım çalışması, verimlilik gibi önemli unsurlardır. Konuyla ile ilgili daha genel bir çerçeve sunan Kristof’a (1996: 15) göre birey-örgüt uyumu, bir biriyle ilişkili dört parçadan oluşmaktadır: (1) hem birey hem de örgütün temel özellikleri arasındaki uyum, (2) bireysel ve örgütsel amaçlar arasındaki uyum, (3) kişisel ihtiyaçlar ile örgütün yapısı arasındaki uyum, (4) örgüt iklimi ve kişisel özellikler arasındaki uyum. Buna istinaden Carles (2005) çalışanın örgütü ile kendisi arasında benzerlik kurmasının, birey-örgüt uyumu açısından bir ön koşul olduğunu ileri sürmüştür.

Bright'a (2007: 364) göre birey-örgüt uyumu benzerlik (supplementary) ve tamamlayıcı (complementary) uyum olarak ifade edilen iki yöntemlerle kazanılır. Benzerlik uyumu; bireyin sahip olduğu özellikler, değerler ve normların örgütle benzeşmesi durumudur (Cable ve Edwards, 2004: 823). Bireyin 
özellikleriyle örgütün özeliklerinin benzemesi veya bireyin gereksinimlerinin örgüt tarafından karşılanması ile birlikte; örgüte bağlılık, iş doyumu, performans artışı, bireyin iyi oluşu ve mutluluk gibi pozitif sonuçlar ortaya çıkmaktadır. Tamamlayıcı uyum ise, birey ve örgüte ait özelliklerin bir diğerinin eksik kalan bir ihtiyacını karşılaması durumudur. Tamamlayıcı uyum; ihtiyaç-tamamlama uyumu (needssupplies fit) ve talep-yetenek uyumu (demands-abilities fit) olarak iki şekilde tanımlanır. Bireyin ihtiyaçları ile örgütün bu ihtiyaçları karşılaması arsındaki uyum ihtiyaç tamamlama uyumu olarak tanımlanırken, bireyin sahip olduğu bilgi, beceri ve yetenekler sayesinde örgütün gereksinimlerinin karşılanması ise talep-yetenek uyumu diye adlandırılır (Kristof, 1996: 17). Silverthorne’a (2004: 595) göre bireyin ihtiyaçları ve örgütten beklentileri; iş güvenliği, iyi çalışma koşulları, iyi ücret, diğer insanlarla birlikte olma, örgütsel iklime dâhil olma, iyi yönetim, becerilerini gösterebilme, sorumluluk alabilme, terfi fırsatı, başarı hissi gibi sıralanmaktadır. Örgütün ihtiyaçları ve bireyden beklentileri ise; örgütün amaçlarına bağlılık, direktiflere uyma, otoriteye saygı, örgüte bağlılık, çok çalışma, çalışanların iş birliği, iş arkadaşları ile dostluk, yaratıcılık, kaliteli iş, işgören doyumu olarak sıralanmaktadır. Birey-örgüt uyumunun sağlanamadığı örgütlerde ise çalışanlarda performans düşüklüğü, yabancılaşma ve yalnızlık gibi davranışlar görülürken, örgütsel çatışma, stres ve işten ayrılma niyetlerinde artış olmaktadır (Ulutaş, 2010: 90).

\section{Örgütsel Yabancılaşma}

Yabancılaşma kavramı erken dönem araştırmalarına göre, bireylerin kendi ürettikleri nesnelere ve eylemlere yabancılaşması olarak tanımlanmış; ancak daha sonra kavramın boyutları genişletilerek, bireyin kendi yaşamına ve diğer bireylere yabancılaşması durumu olarak ifade edilmiştir. Örgütsel anlamda yabancılaşma ise çalışan ilişkileri kapsamında ele alınmaktadır (Kurtulmuş ve Karabıyık, 2016: 463). Genel anlamıyla örgütsel yabancılaşma bireylerin örgütsel değerler, kurallar ve ilişkilerden uzaklaşması halidir. Örgüt içerisinde bireyler sınırları başkaları tarafından çizilen bir dünyada yaşamakta; iş ve iş ilişkilerine kendi duygu ve düşüncelerini yansıtamamaktadırlar. Dolayısıyla kendilerini yalnızca iş sürecine katkıda bulunan robotlar olarak gören bireyler örgüte yabancılaşmaktadırlar (Şimşek, Çelik ve Akgemici, 2016: 256). Üngüren ve arkadaşlarına göre örgütsel yabancılaşma çalışanların duygusal, fiziksel ve bilişsel yeteneklerini üretim sürecine aktaramamaları sonucu gelişen bir durumdur (Üngüren, Kaçmaz ve Yılmaz, 2016: 4). Marx’a (2013: 298) göre ise bireyin örgüte yabancılaşması, aşırı iş bölümü sonucundur. Çünkü iş bölümü, çalışanları düşük nitelikte vasıf gerektiren veya hiçbir vasıf gerektirmeyen işlerde uzmanlaştırarak; üretim süreci ve gerçek ürün ile olan bağını keser. Böylece birey klasik yönetim kuramlarının da temel varsayımlarından bir olan değiştirilebilir bir makine parçası haline dönüşerek hem 
ürüne hem de üretim faaliyeti boyunca kendi emeğine yabancılaşır; çünkü hayatta kalmak için emeğini metalaştırmakta ve dışsallaştırmaktadır. Başka bir açıdan örgütsel yabancılaşma çalışanların objektif görev koşulları algıları ile bu koşullara ilişkin beklentileri arasındaki uyumsuzluk olarak tanımlanabilir. Söz konusu uyumsuzluk ise önce güçsüzlük ve anlamsızlıkla; belirli bir zaman sonra ise kendine yabancılaşma ile sonuçlanmaktadır. Yabancılaşan bireyler de özgürce hareket edemediklerini ve bağlı bulundukları örgüte herhangi bir katkı sağlamadıklarını düşünmekte; örgüt faaliyetlerini kendileri dışında işleyen bir süreç olarak görmektedirler (Rajaeepour, Arbabisarjou, Zivarirahman ve Shokouhi, 2012: 189). Bunlara ek olarak örgüt içerisinde yer alan idarecilerin gereksiz sertlikteki yönetim anlayışları, iş görenlerin örgütten yabancılaşmasına ve daha saldırgan bir kimliğe bürünerek sert tepkiler göstermelerine neden olmaktadır (Fettahlığlu, 2006: 45) Örgütsel yapı ve normlarla belirlenen rol ve görevleri yerine getirmekle sorumlu olan ama ne ürettiği ürün üzerinde kontrole ne de harcadığı emeği üzerinde söz hakkına sahip olamayan bireyde giderek güçsüzlük hissi ortaya çıkmaktadır. Bu da içerisinde bulunduğu duruma ve örgütsel normlara anlam verememesine neden olmaktadır. Daha sonra da birey anlamlandıramadığı örgütsel normları reddetmeye başlamaktadır. Bu kuralsızlık davranışı ise bireyin örgütsel ortama uyum sağlayamamasına ve giderek kendini izole etmesine neden olmaktadır. Devam eden izolasyon hali ise bireyi hem örgütüne hem de kendine yabancılaştırmaktadır (Seeman, 1983: 172).

Seeman (1983: 173) bireyin kendi davranışları ve etrafındaki olaylar hakkında denetimini yitirmesi sonucu ortaya çıkan yetersizlik düşüncesini güçsüzlük şeklinde ifade etmiştir. Başka bir ifade ile güçsüzlük, bireyin başkaları tarafından kullanılma ve yönetilme deneyimlerine bağlı olarak çevresinde meydana gelen olayları kontrol edememe durumudur (Tummers, Bekkers, Van Thiel ve Steijn, 2015: 600). Bu durumun bireyde oluşturduğu duygu ise, bireyin başarısızlık kaygısından ve kendisini tek başına yetersiz görmesinden kaynaklanmaktadır (Soysal, 1997: 28). Anlamsızlık, bireyin yaptığı işin bütüne (örgüte) katkı sağlamadığını düşündüğünde veya yapmak istediği iş ile örgütün bireye tanımladığı rol arasında çatışma olduğunda ortaya çıkar. Özellikle büyük çaplı örgütlerde her işin çok farklı ve fazla sayıda uzmanlaşmayı gerektirmesi, bireyin diğerlerinin işleri hakkında herhangi bir bilgiye sahip olmaması anlamsızlığa yol açar (Sarros, Tanewski, Winter, Santora ve Densten, 2002: 287). Seeman'a (1983: 174) göre ise anlamsızlık, bireyin kendi değerleri ve doğruları ile örgütün veya toplumun değerli veya doğruları arasında çelişkiye düştüğünde, bireyin neye inanması gerektiğine karar verememesin sebep olduğu çıkmazı açıklamak için kullanılan bir kavramdır. Kuralsızlık (normsuzluk), örgütsel normların bireyin amaçlarıyla ve inançlarıyla uyuşmadığında, bireyin toplum ve örgüt kurallarını görmezden gelmesi ve bu kuralları benimsemekten kaçınması durumudur (Tribe ve Mkono, 2017: 107). Böyle bir 
durumda birey, kişisel hedeflerini gerçekleştirmek için sosyal açıdan kabul görmeyen yolara başvurarak toplumsal ve örgütsel normlardan uzaklaşmaktadır (Seeman, 1983: 176). Fakat bu uzaklaşma da bireyin giderek örgütten yabancılaşmasına sebep olmaktadır (Soysal, 1997: 28). İzolasyon (yalıtılmışlık), bireyin

toplumu ve sosyal yaşamı güvensiz görülmesi nedeniyle toplumdan uzak durma davranışıdır (Silah, 2005: 210). Örgütsel anlamda izolasyon ise bireyin sosyal çıkar kaybını göze alarak kendini her türlü örgütsel ilişkiden bilinçli olarak uzak tutmasıdır (Seeman, 1983: 177). İzolasyon genelde, örgütsel normları reddeden (Soysal, 1997: 29) ve örgütte kendini yalnız hisseden bireylerde görülmektedir (Şimşek vd., 2016: 255). Bununla birlikte kendi izole eden bireyler ortak amaçları benimsenmemekte ve örgüte karşı her hangi bir bağlılık hissetmemektedirler (Silah, 2005: 210). Eğitim örgütlerinde izolasyon ise öğretmenin kendini eğitim-öğretim ile ilgi tüm süreçlerden uzaklaştırması şeklinde ortaya çıkmaktadır (Erjem, 2005: 398). Soysal (1997: 29) kendine yabancılaşmayı bireyin kendi potansiyelinin farkında olmamasından dolayı benliğini ve yeteneklerini kendine ait hissetmeme durumunu olarak tanımlamıştır. Mottaz’a (1981: 517) göre ise bireyin beklentileri ile örgütsel eylemlerinin örtüşmesidir. O’Donohue ve Nelson'a (2014: 304) göre kendine yabancılaşma iş sürecinin bireyi örgütsel bütünlük ve bağl1lıktan yoksun bıraktığında ortaya çıkmaktadır.

Bu bilgiler 1şığında araştırma kapsamında geliştirilen hipotezler şu şekildedir:

H1: Öğretmenlerin pozitif psikolojik sermaye düzeyleri, yabancılaşma düzeylerini etkiler

H2: Öğretmenlerin örgüte olan uyumu, örgüte yabancılaşmalarını etkiler.

H3: Öğretmenlerin pozitif psikolojik sermaye düzeyleri, öğretmenlerin örgüte olan uyumunu etkiler.

H4: Öğretmenlerin pozitif psikolojik sermaye düzeylerinin, örgüte yabancılaşma etkisinde birey örgüt uyumunun aracılık rolü vardır.

\section{YÖNTEM}

\section{Araştırma Modeli}

$\mathrm{Bu}$ araştırmanın devlet okullarında görev yapan öğretmenlerin, uyumu ile pozitif psikolojik sermaye ve birey-örgüt uyumu ile örgütsel yabancılaşma algıları arasındaki yapısal ilişkileri için ilişkisel tarama modelinde desenlenmiştir. İlişkisel tarama modelindeki araştırmalar, iki veya daha fazla değişken arasında ilişkinin olup olmadığını inceleyen ve bu ilişkinin ne tür bir ilişki olduğunu açıklayarak, değişskenler hakkında tahminlerde bulunabilmek için tasarlanan deneysel olmayan araştırmalardır (Christensen, Johnson ve Turner, 2010: 62). 


\section{Evren-Örneklem}

Araştırmanın evrenini 2018-2019 Eğitim-Öğretim yılında Eskişehir ili Tepebaşı ilçe merkezindeki devlet okullarında görev yapmakta olan öğretmenler oluşturmaktadır. Tepebaşı İlçe Milli Eğitim Müdürlüğünden alınan bilgilere göre Tepebaşı ilçesinde 21 ilkokul ve ortaokul, 26 genel ortaöğretim ve 21 mesleki ve teknik orta öğretim olmak üzere toplam 68 tane okul vardır. Bu okullarda toplam 2790 öğretmen görev yapmaktadır. Araştırma grubunun belirlenmesinde örneklem büyüklüğü hesaplama formülü, tabakalı örnekleme ve seçkisiz örnekleme yöntemleri aşamalı olarak kullanılmıştır. Örneklem büyüklüğü hesaplama formülü evren hakkında bazı temel bilgiler bilindiği zaman ulaşılması gereken en az katılımcı sayısını veren istatistiksel bir yöntemdir. Tabakalı örnekleme yönteminde alt tabakalar belirlenerek genelleme yapıldığı için everenini temsil etme gücü yüksek ve örneklem hatası ise düşüktür (Arıkan, 2013: 121). Seçkisiz örneklemede ise evren içerisindeki her bir elemanın örnekleme dahil olma olasılığ1 eşittir (Yıldırım ve Şimşek, 2005: 54). Araştırmanın ilk aşamasında örneklem büyüklüğü hesaplama formülü kullanılarak \%95 güven aralığında ulaşılması gereken en az kişi sayısı 338 olarak belirlenmiştir. İkinci aşama olan tabakalı örneklemede kriter olarak okul düzeyleri kullanılmıştır. Bu doğrultuda 2 ilkokul ve 2 ortaokul, 4 mesleki ve teknik ortaöğretim ve 6 genel orta öğretim okullarında görev yapan öğretmenler örnekleme dahil edilmiştir. Bir sonraki aşamada rast gele örnekleme yöntemiyle bu tabaklardan veri toplanmıştır. Araştırmada analiz edilebilir 456 adet veriye ulaşıılmıştır. Örneklem grubunu oluşturan öğretmenlerin demografik özelliklerine ilişkin veriler Tablo 1'de gösterilmiştir

Tablo 1. Araştırmaya Katılan Öğretmenlerin Kişisel Özelliklerine İlişkin Veriler

\begin{tabular}{|c|c|c|c|c|c|}
\hline & $\mathbf{N}$ & $\%$ & & $\mathbf{N}$ & $\%$ \\
\hline Cinsiyet & & & Yaş & & \\
\hline Kadın & 293 & 64.3 & $20-30$ yaş & 61 & 13.4 \\
\hline Erkek & 163 & 35.7 & $31-40$ yas & 290 & 63.6 \\
\hline Eğitim Durumu & & & $41-50$ yaş & 88 & 19.3 \\
\hline Lisans & 352 & 77.2 & $51+$ & 17 & 3,7 \\
\hline Yüksek Lisans & 93 & 20.4 & Medeni Durum & & \\
\hline Doktora & 11 & 2.4 & Evli & 387 & 84.9 \\
\hline Deneyim & & & Bekar & 69 & 15.1 \\
\hline $1-5$ y1l & 48 & 10,5 & Calıșma Yılı & & \\
\hline $6-10$ y1l & 46 & 10,1 & 1 Yıldan az & 72 & 15.8 \\
\hline $11-15$ y1l & 108 & 23,7 & $1-3$ & 144 & 31.6 \\
\hline $16-20$ y1l & 130 & 28,5 & $4-7$ & 126 & 27.6 \\
\hline $21+y 11$ & 124 & 27,2 & $8+$ & 114 & 25.0 \\
\hline
\end{tabular}

Araştırmaya katılan öğretmenlerin demografik verilerine ilişkin analizler frekans analizi aracılığıyla yapılmıştır. Buna göre katılımcıların \%64,3'ünün kadın ve \%35,7'sinin erkek olduğu görülmektedir. Araştırmaya katılanların \%84,9'unun evli ve \%15,1'inin bekâr olduğu tespit edilmiştir. Katılımcıların yaş 
grupları incelendiğinde en yüksek oran \%63,6 ile 31-40 yaş arasında olduğu görülmektedir. Araştırmaya katılanların \%77,2'sinin lisans, \%20,4'ünün de yüksek lisans mezunu olduğu tespit edilmiştir. Katılımcıların mesleki deneyimleri incelendiğinde, \%28,5'inin 16-20 yıl, \%27,2'sinin 25 yıl ve üzeri, \%23,7'sinin de 11-15 yıl arasında olduğu görülmektedir. Mevcut kurumdaki çalışma sürelerine bakıldığındaysa ilk iki sırada \%31,6 ile 1-3 yıl, \%27,6 ile 4-7 yıl arası çalışan öğretmenlerin olduğu görülmektedir.

\section{Veri Toplama Araçları ve Analiz Yöntemi}

Bu çalışmada, öğretmenlerin pozitif psikolojik sermaye algılarını ölçmek amacıyla Tösten ve Özkan'ın (2014: 429) geliştirmiş olduğu "öz yeterlilik, iyimserlik, güven, dışa dönüklük, psikolojik dayanıklılık ve umut " boyutlarından oluşan yirmi altı ifadelik Pozitif psikolojik sermaye ölçeği kullanılmıştır. Ölçeğin tamamı için hesaplanan Cronbach Alpha katsayısı .92'dir. boyutların ise güvenirlik katsayıları .61 ile .93 arasında değişmektedir. Birey-örgüt uyumu düzeyini belirlemek üzere Netemeyer, Boles, McKee ve McMurrian'ın (1997: 85) geliştirdiği dört maddeli ölçek kullanılmıştır. Ölçek, Elçi, Alpkan ve Çekmecioğlu (2008: 587) tarafından Türkçe’ye uyarlanmış ve tek boyutludur. Ölçeğin Cronbach Alpha katsayısı. 73'tür. Örgütsel yabancılaşmayı ölçmek için Mottaz (1981: 515) tarafından geliştirilen ölçekten yararlanılmıştır. Ölçeğin Türkçe uyarlaması Işkın (2015: 260) tarafından yapılmıştır. Ölçek, güçsüzlük boyutu dört, anlamsızlık boyutu iki, kuralsızlık boyutu iki, izolasyon boyutu üç ve kendine yabancılaşma boyutu üç ifade olmak üzere toplam on dört ifadeden oluşmaktadır. Ölçeğin tamamı için hesaplanan Cronbach Alpha katsayısı .88'dir. boyutların ise güvenirlik katsayıları .62 ile .85 arasında değişmektedir.

Bağımlı ve bağımsız değişkenler arasındaki ilişkiyi ölçebilmek için korelasyon analizi yapılmıştır. Pozitif psikolojik sermaye ve birey-örgüt uyumunun, yabancılaşma algısını yordama düzeyinin tespit edilebilmesi amacıyla çoklu doğrusal regresyon modeli kullanılmıştır. Pozitif psikolojik sermayenin, birey-örgüt uyumu değişkeni aracıllğı ile öğretmenlerin örgütsel yabancılaşmalarını yordayıp yordamadığını test etmek için Baron ve Kenny'in (1986: 1178) 3 adımlı yöntemi ve dolaylı etkinin anlamlılığını ölçmek için sobel testi kullanılmıştır.

\section{BULGULAR}

\section{Tanımlayıcı İstatistikler ve Değişkenler Arasındaki İlişkilere Yönelik Bulgular}

Örgütsel yabancılaşma, birey örgüt uyumu ve pozitif psikolojik sermaye boyutları arasındaki ilişkiyi ortaya koyabilmek için korelasyon analizi yapılmıştır. Korelasyon analizi iki ya da ikiden fazla değişken arasında herhangi bir ilişkinin olup olmadığı eğer bir ilişki varsa bulunan ilişkinin şiddetini gösteren bir 
testtir (Büyüköztürk, 2017: 68). Korelasyon katsayısı -1 ile +1 arasında bir değer almaktadır. Korelasyon kat sayılarında 0,00 ile 0,25 "çok zayıf", 0,26 ile 0,49 "zayıf", 0,50 ile 0,69 "orta", 0,70 ile 0,89 "yüksek", 0,90 ile 1,00 ise "çok yüksek" ilişki olduğunu göstermektedir (Sungur, 2016, s. 117). Bu analize ilişskin sonuçlar Tablo 2'de yer almaktadır.

Tablo 2. Değişkenlere İlişkin Ortalamalar, Standart Sapma Değerleri, Güvenilirlik Katsayıları ve Korelasyon Katsayıları

\begin{tabular}{|c|c|c|c|c|c|c|c|c|c|c|c|c|}
\hline D & 1 & 2 & 3 & 4 & 5 & 6 & 7 & 8 & 9 & 10 & 11 & 12 \\
\hline 1 & $(0,81)$ & & & & & & & & & & & \\
\hline 2 & ,669 & $(0,73)$ & & & & & & & & & & \\
\hline 3 & ,465 & ,464 & $(0,62)$ & & & & & & & & & \\
\hline 4 & ,475 & ,493 & ,447 & $(0,64)$ & & & & & & & & \\
\hline 5 & ,454 &, 543 &, 500 & ,639 & $(0,85)$ & & & & & & & \\
\hline 6 &,- 343 &,- 276 &,- 190 &,- 289 &,- 204 & $(0,73)$ & & & & & & \\
\hline 7 &,- 284 &,- 353 &,- 333 &,- 398 &,- 454 &, 338 & $(0,93)$ & & & & & \\
\hline 8 &,- 233 &,- 278 &,- 267 &,- 389 &,- 373 &, 376 & ,645 & $(0,68)$ & & & & \\
\hline 9 &,- 482 &,- 522 &,- 474 &,- 947 &,- 759 & ,284 & ,423 & ,384 & $(0,72)$ & & & \\
\hline 10 &,- 250 &,- 295 &,- 259 &,- 328 &,- 352 &, 301 & 663 &, 567 &, 313 & $(0,75)$ & & \\
\hline 11 &,- 262 &,- 299 &,- 228 &,- 306 &,- 308 & ,272 & ,606 &, 565 & ,287 &, 752 & $(0,93)$ & \\
\hline 12 &,- 232 &,- 272 &,- 197 &,- 290 &,- 299 & ,186 &, 530 & ,499 &, 270 & ,627 &, 800 & $(0,61)$ \\
\hline Ort. & 2,12 & 1,85 & 1,65 & 1,94 & 1,51 & 3,38 & 4,22 & 4,05 & 4,36 & 4,18 & 4,17 & 4,30 \\
\hline Ss. & 1,213 & ,923 & ,970 & 1,231 & ,902 & 1,224 & ,965 & 1,922 & 1,120 & ,960 & ,909 & ,880 \\
\hline \multicolumn{2}{|c|}{ 1: Güçsüzlük } & \multicolumn{2}{|c|}{ 2: Anlamsızlık } & \multicolumn{2}{|c|}{ 3: Kuralsızlık } & 4: İzolas & \multicolumn{3}{|c|}{ 5: K. Yabancıl1k } & \multicolumn{3}{|c|}{ 6: Birey-Örgüt Uyumu } \\
\hline \multicolumn{2}{|c|}{ 7: Öz yeterlik } & \multicolumn{3}{|c|}{ 8: İyimserlik } & Güven & \multicolumn{3}{|c|}{ 10: D1şa dönüklük } & \multicolumn{2}{|c|}{ 11: P. Dayanıklılık } & \multicolumn{2}{|c|}{ 12: Umut } \\
\hline
\end{tabular}

NOT: $\mathrm{N}: 456, \mathrm{p}<.01$, Cronbach Alpha değerleri parantez içinde verilmiştir

Korelasyon analizine göre pozitif psikolojik sermaye ile örgütsel yabancılaşmanın hemen hemen tüm alt boyutları arasında zayıf ve orta düzeyde ters yönlü ilişkiler bulunurken, pozitif psikolojik sermayenin güven alt boyutu ile örgütsel yabancılaşmanın izolasyon alt boyutu arasında çok yüksek düzeyinde ters yönlü bir ilişki tespit edilmiştir. Pozitif psikolojik sermayenin alt boyutları ile birey-örgüt uyumu arasında doğru yönlü ve zayıf ilişkiler olduğu görülmüştür. Birey-örgüt uyumu ile örgütsel yabancılaşmanın alt boyutları arasında ise ters yönlü ve zayıf ilişkiler olduğu bulgulanmıştır. Özetle, öğretmenlerin örgüte olan uyumları ile pozitif psikolojik sermaye algıları arttıkça yabancılaşma düzeyleri azalmaktadır. Araştırma değişkenlerinin ortalamaları incelendiğinde ise öğretmenlerin örgütsel yabancılaşma algılarının nispeten 
düşük, birey-örgüt uyumlarının orta ve pozitif psikolojik sermayelerinin yüksek düzeyde olduğu görülmektedir.

\section{Çoklu Regresyon Analizine Yönelik Bulgular}

Araştırma değişkenleri arasındaki ilişkilere bakıldıktan sonra bağımsız değişkenlerin, bağımlı değişkene ait toplam varyansdaki değişimleri ne oranda açıklayabildiğini, yani bağımlı değişkeni etkileyip etkilemediklerini, etkiliyorsa anlamlılığını ve etkileme düzeyini belirleyebilmek için çoklu doğrusal regresyon modeli kullanılmıştır. Bu model bağımsız değişkenlerin bağımlı değişkende açıkladığı toplam ve tekil varyans miktarı arasında karşılaştırmalar yapmayı sağlar. Regresyon analizinde çoklu doğrusal bağıntı veya otokorelasyon sorunlarının olup olmadığı değişkenlerin tolerans, VIF ve Durbin-Watson değerleriyle kontrol edilmiştir (Hair, Black, Babin ve Anderson, 2010: 658). Çoklu regresyon analizine ilişkin bulgular ise Tablo 3'de sunulmuştur.

Tablo 3. Pozitif Psikolojik Sermaye Alt Boyutları ile Birey Örgüt Uyumunun Örgütsel Yabancılaşmayı Yordamasına İlişkin Çoklu Regresyon Analizi

\begin{tabular}{|c|c|c|c|c|c|}
\hline $\begin{array}{l}\text { Bağımsız } \\
\text { Değișkenler }\end{array}$ & $\boldsymbol{\beta}$ & $\begin{array}{c}\text { Standart } \\
\text { Hata }\end{array}$ & $\begin{array}{l}\text { Standart } \\
\text { Ed. } \beta\end{array}$ & $\mathbf{t}$ & $\mathbf{p}$ \\
\hline Sabit & 2,356 &, 143 & & 16,470 &, 000 \\
\hline Birey Örgüt Uyumu &,- 085 & ,023 &,- 177 & $-3,690$ &, 000 \\
\hline Öz yeterlilik &,- 118 &, 041 &,- 191 & $-2,874$ & ,004 \\
\hline İyimserlik &,- 023 & ,032 &,- 043 &,- 716 & ,474 \\
\hline Güven &,- 001 &, 047 &,- 001 &,- 012 & ,990 \\
\hline Dışadönük &, 037 &, 057 &, 058 & ,641 &, 522 \\
\hline Dayanıklılık &,- 036 &, 055 &,- 053 &,- 643 &, 520 \\
\hline Umut &,- 014 &, 028 &,- 029 &,- 497 & ,619 \\
\hline $\mathrm{R}=0,339$ & $\mathrm{R}^{2}=0,115$ & & \multicolumn{3}{|c|}{ Durbin-Watson $=1,536$} \\
\hline
\end{tabular}

Regresyon katsayılarının anlamlılığına ilişkin analiz sonuçları incelendiğinde, pozitif psikolojik sermaye alt boyutları ile birey örgüt uyumunun, örgütsel yabancılaşmayı etkileyen anlamlı bir etken olduğu (p< 0,01) belirlenmiştir. Buna göre $\mathrm{H}_{2}$ hipotezi desteklenmiştir. Pozitif psikolojik sermaye alt boyutları ile birey örgüt uyumunun, örgütsel yabancılaşmaya etkisine ilişkin toplam varyans yükü $\left(\mathrm{R}^{2}: 0,115\right)$ olarak hesaplanmıştır. Yani pozitif psikolojik sermaye alt boyutları ile birey örgüt uyumunun örgütsel yabancılaşmaya etkisi toplam varyansın yaklaşık \%11,5'ini açıkladığı görülmüştür. 


\section{Pozitif Psikolojik Sermayenin Yabancılaşma Üzerindeki Etkisinde Birey Örgüt Uyumunun Aracılık Etkisine Yönelik Bulgular}

Pozitif psikolojik sermayenin, birey örgüt uyumu değişkeni aracıllğı ile öğretmenlerin örgütsel yabancılaşmalarını etkileyip etkilemediği şekil 1'deki model ile test edilmiştir. Aracılık etkisinden söz edebilmek için, üç şartın sağlanması zorunludur. İlk olarak, bağımsız değişkenin aracı değişkeni etkilemesi gerekmektedir. İkinci olarak, aracı değişken olan birey örgüt uyumu ile bağımlı değişken olan yabancılaşma arasında anlamlı bir ilişki olmalıdır. Üçüncü olarak, bağımlı değişken üzerinde bağımsız değişkenin etkisi, ikinci eşitlikte olduğundan daha az olmalıdır. Eğer, bağımsız değişken bağımlı değişken üzerinde hiçbir etkiye sahip değilse tam aracılık, bağımsız değişkenin etkisi ikinci eşitlikte olduğundan daha az ise kısmi aracılık söz konusudur (Usta, 2010: 255). Şekil 1'de yer alan modeldeki X bağımsız değişkeni (pozitif psikolojik sermaye), Y bağımlı değişkeni (yabancılaşma) ve $\mathrm{M}$ aracı (birey örgüt uyumu) değişkeni temsil eder. Ayrıca, c yolu bağımsız değişken ile bağımlı değişken arasındaki etkiyi, b ise aracı değişken ile bağımlı değişken arasındaki etkiyi gösterir (Baron ve Kenny, 1986: 1178).

\section{Şekil 1: Aracılık Etkisini Gösteren Araştırma Modeli}

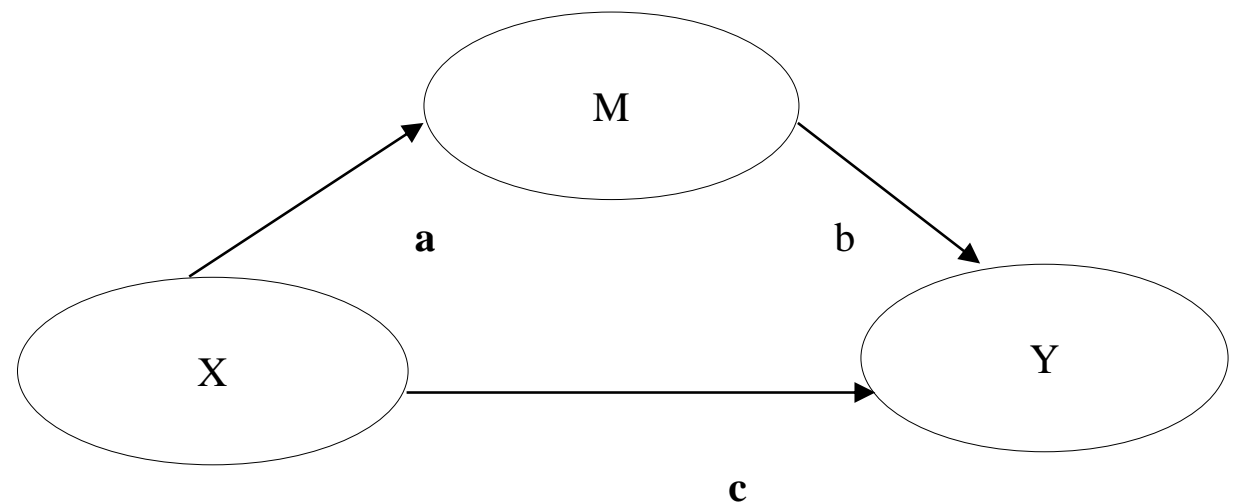

Araştırmada varsayılan modeldeki aracıllk etkisini istatistiksel olarak anlamlı olup olmadığını test etmek için üç regresyon eşitliği kullanılmıştır.

1. Eşitlik: $M=\beta_{0}{ }^{1}+\beta_{1}{ }^{l} X$

2. Eşitlik: $Y=\beta_{0}{ }^{2}+\beta_{1}{ }^{2} X$

3. Eşitlik: $Y=\beta_{0}{ }^{3}+\beta_{1}{ }^{3} X+\beta_{2}{ }^{3} M$

İlk olarak, birey örgüt uyumu (aracı değişken) üzerinde pozitif psikolojik sermayenin (bağımsız değişken) etkisine bakılmaktadır. İkinci eşitlikte, pozitif psikolojik sermayenin, yabancılaşma (bağımlı değişken) üzerindeki etkisi araştırılmaktadır. Üçüncü eşitlikte ise bağımlı değişken (yabancılaşma) üzerinde aracı değişken (birey-örgüt uyumu) ile beraber bağımsız değişkenin (pozitif psikolojik sermaye) etkisi araştırılmaktadır. Aracılık etkisi ile ilgili 3 tane hipotez kurulmuştur. Hipotezleri test etmek için Baron ve 
Kenny'in 3 adımlı yöntemi ve dolaylı etkinin anlamlılığını ölçmek için Sobel Testi kullanılmıştır. Şekil 2 'de Sobel testine göre aracılık etkisini gösteren araştırma modeli yer almaktadır.

\section{Şekil 2: Sobel Testine Göre Birey Örgüt Uyumunun Aracılık Etkisini Gösteren Araştırma Modeli}

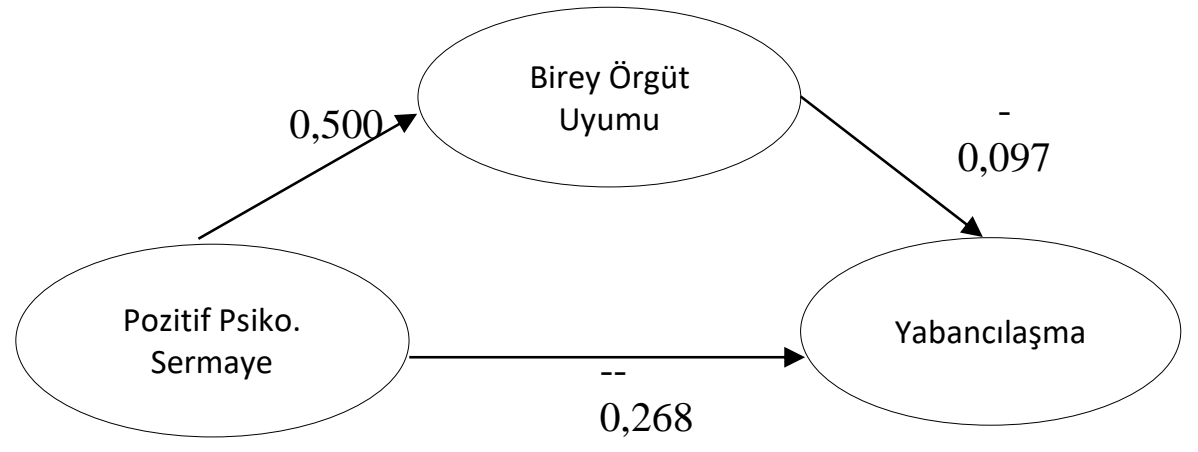

Tablo 4. Değişkenlere İlişsin Aracılığı Gösteren Sobel Testi

\begin{tabular}{|c|c|c|c|c|}
\hline \multirow[b]{2}{*}{ Değişkenler } & \multirow{2}{*}{$\begin{array}{l}\mathrm{M}=\beta_{0}{ }^{1}+\beta_{1}{ }^{1} \mathrm{X} \\
\text { 1. Eşitlik: (Aracı Değişken=f } \\
\text { (bağımsız değişken) } \\
\text { (a) }\end{array}$} & \multirow{2}{*}{$\begin{array}{c}\mathrm{Y}=\beta_{0}{ }^{2}+\beta_{1}{ }^{2} \mathrm{X} \\
\text { 2. Eşitlik: Bağımlı } \\
\text { Değişken=f (bağımsız } \\
\text { değişken) } \\
\text { (c) }\end{array}$} & \multicolumn{2}{|c|}{$\begin{array}{c}\mathrm{Y}=\beta_{0}{ }^{3}+\beta_{1}{ }^{3} \mathrm{X}+\beta_{2}{ }^{3} \mathrm{M} \\
\text { 3. Eşitlik: Bağımlı Değişken=f(bağımsız } \\
\text { ve aracı değişken) }\end{array}$} \\
\hline & & & $\left(c^{\prime}\right)$ & (b) \\
\hline $\begin{array}{c}\mathrm{X}^{*} \\
\mathrm{M}^{* *}, \mathrm{Y}^{* * *}\end{array}$ & $\begin{array}{c}\beta_{1}{ }^{1}=.500 \\
t=7.361 \\
p=.0001 \\
\text { Std. Hata }=.068\end{array}$ & $\begin{array}{c}\beta_{1}^{2}=-.268 \\
t=-6.462 \\
p=.0001 \\
\text { Std. Hata }=0.41\end{array}$ & $\begin{array}{c}\beta_{1}^{3}=-.219 \\
t=-5,065 \\
p=.0001 \\
\text { Std. Hata }=.043\end{array}$ & $\begin{array}{c}\beta_{2}{ }^{3}=-.097 \\
t=-3,414 \\
p=.0001 \\
\text { Std. Hata }=.028\end{array}$ \\
\hline
\end{tabular}

*X: Pozitif psikolojik Sermaye, **M: Birey-Örgüt Uyumu, ***Y: Örgütsel Yabancılaşma

Tablo 4'e göre pozitif psikolojik sermayenin birey örgüt uyumu üzerinde pozitif ve anlamlı bir etkisi vardır $\left(\beta_{1}{ }^{1}=.500, p<0.01\right)$. Buna göre $\mathrm{H}_{3}$ hipotezi desteklenmiştir. İkinci eşitliğe göre, pozitif psikolojik sermayenin yabancılaşma üzerinde negatif ve anlamlı bir etkisi vardır $\left(\beta_{1}{ }^{2}=-.268, \mathrm{p}<0.01\right)$. Buna göre $\mathrm{H}_{1}$ hipotezi de desteklenmiştir. Son eşitlikte, bağımsız değişken (pozitif psikolojik sermaye) ile aracı değişken (birey-örgüt uyumu) modele birlikte dahil edilmiş ve bağımlı değişen (yabancılaşma) açıklanmaya çalışılmaktadır. Üçüncü eşitliğe bakıldı̆̆ında, pozitif psikolojik sermaye ile yabancılaşma arasındaki ilişkinin anlamsızlaşmadığı, fakat etki düzeyinin azaldığı görülmektedir $\left(\beta_{1}{ }^{3}=-.219, \mathrm{p}<0.01\right)$. Beta değerindeki azalma miktarının anlamlılık düzeyine Sobel testi ile bakılmıştır. Sobel testi sonuçları $\mathrm{Z}=-3.13, \mathrm{p}<0.001$ şeklindedir. Bu sonuca göre Beta değerinde meydana gelen azalma anlamlıdır. Buna 
göre, pozitif psikolojik sermaye ile yabancılaşma arasında birey örgüt uyumunun kısmi aracı etkiye sahip olduğunu söylenebilir. Bu bağlamda, $\mathrm{H}_{4}$ hipotezi desteklenmiştir.

\section{SONUÇ}

Araştırmada, öğretmenlerin pozitif psikolojik sermaye algılarının yüksek düzeyde olduğu sonucuna ulaşılmıştır. Literatürde bu bulguyu destekleyecek çalışmalara rastlanmaktadır (Çimen, 2015: 100; Erbaş, 2018: 83; Keser, 2013: 118; Tösten, 2015: 136). Pozitif psikolojik sermayenin boyutları açısından katılım ortalamalarına göre en yüksek katılım gösterilen boyutlar sırasıyla "güven, umut ve öz yeterlilik" boyutlarıdır. Güven boyutun en çok katılım puanına sahip olması, öğretmenlerin mesleğinin bilincinde ve sorumluluk sahip olduğunu göstermektedir. Okulun tüm paydaşlarının öğretmenlere olan güvenin yüksek olduğunu, hesap verilebilirlikte nerdeyse hiç problem yaşamadıkları yorumu yapılabilir. Özellikle öğretmenin öğrencileriyle güven ilişkisi içerisinde ve onların sorunlarına ilişkin yardımcı olmakta istekli oldukları sonucuna varılabilmektedir. Ayrıca öğretmenlerin umut ve öz yeterlilik algılarının yüksek düzeyde çıkması, onların bir görevi yerine getirebilmek için gerekli motivasyon ve güce sahip olduklarını göstermektedir. Zorluklara rağmen olgunlukla hareket ettikleri ve vazgeçmedikleri yorumu yapılabilir. Araştırmada düşük puanı alan psikolojik sermaye boyutu iyimserliktir. Bu bulgu Çimen'in (2015: 101) çalışmasıyla da örtüşmektedir. Buna göre öğretmenlerin geleceğe güvenle bakmadığı yorumu yapılabilir.

Öğretmenlerin birey-örgüt uyumlarının orta düzeyde olması, okulun tam anlamıyla öğretmenin ihtiyaçlarını karşılamadığı, ortak değerlere ve amaçlara sahip olunmadığı yorumu yapılabilir. Eksik kalan hususlar; okul yönetiminde öğretmenin etkin olamaması, isteklerinin dikkate alınmaması, okuldaki diğer öğretmenlerle kurulan ilişkilerde ortak inanç ve değerlerin olmaması öğretmenin kendisini o kuruma ait olmadığını düşündürebilir. Öğretmenin okul yöneticileri ve diğer öğretmenlerden beklentilerinin yanı sıra öğrenci ve velilerden de önemli istekleri olmaktadır. Öğrencilerin sorumluluklarını bilmemesi, derslere ilgisiz kalması ve başarısızlı̆ı̆, öğretmenin motivasyonunu düşürebilir dolayısıyla çalışma şevki kırılan ve amaçlarını gerçekleştiremeyen öğretmen çalışıı̆ı okula uyumlu olmadığını düşünebilir. Ayrıca velilerin sorumluluklarını yerine getirmemesi ve öğretmene desteğinin olmaması da bir uyum problemi olarak değerlendirilebilir.

Araştırma sonuçlarına göre, öğretmenlerin yabancılaşma sorularına genel olarak düşük seviyede katılım gösterdikleri görülmektedir. $\mathrm{Bu}$ durum öğretmenler arasında yabancılaşmanın düşük düzeyde olduğunu göstermektedir. Bu sonuç literatürdeki birçok çalı̧̧mayla benzerlik göstermektedir (Averbek, 2016: 91; Eryılmaz, 2010: 92; Ünsal, 2018: 254). Eğitim örgütlerinde yabancılaşmanın düşük düzeyde çıkmasının 
sebepleri arasında, öğretmenliğin saygın ve kutsal bir meslek olarak görülmesi, öğretmenin mesleğini severek ve isteyerek seçmesi, kamuda görev yapan öğretmenin özlük haklarının birçok kuruma göre daha iyi olması, hayat boyu iş garantisinin olması, bir takım öğretmene özel hizmetlerin (öğretmen evleri, sosyal tesisler, ödenekler, indirimler vb.) bulunması yabancılaşmayı azaltabilir. Yabancılaşmanın boyutları açısından sonuçlara bakıldığında, öğretmenler yabancılaşmayı en çok güçsüzlük boyutunda hissetmektedir. Öğretmenin yaptı̆̆ iş üzerinde kontrolünün olmadığını düşünmesi hatta kendi çalışma yöntemini bile özgürce seçememesi sonucunda kendisini güçsüz hissetmektedir. Bu durum, eğitim örgütlerinin aşırı merkeziyetçi ve bürokratik yapısı, öğretim süreçlerinin dışarıdan belirlenmesi, demokratik olmayan yönetim biçimi, eğitim ile ilgili yasal metinlerin öğretmenin özgürce hareket etmesini kısıtlaması gibi sebeplerle açıklanmaktadır (Erjem, 2005: 399). Yabancılaşma, en düşük "kendine yabancılaşma" boyutunda görülmektedir. Bu durum öğretmenin kendi öz değerlerini yitirmediğini ve buna uygun davranışlar sergilediğini, kendisinden, mesleğinden ve iş çevresinden uzaklaşmadığını gösterir. Buna istinaden bireysel değerler ile örgütsel değer yargılarının benzeşmesi ile uyumun artacağı yorumu yapılabilir. Birey-örgüt uyum düzeyinin artması ile çalışanın mutlu, örgüte bağlı ve daha verimli çalıştıkları önceki çalışmalarda kanıtlanmıştır (Bright, 2007: 370).

Araştırma sonucunda pozitif psikolojik sermayenin ve birey-örgüt uyumu değişkeninin örgütsel yabancılaşmanın anlamlı bir yordayıcısı olduğu bulunmuştur. Psikolojik sermaye ve birey-örgüt uyumu arasında pozitif yönde, örgütsel yabancılaşma ile negatif yönde bir ilişki olduğu tespit edilmiştir. Bu bulgu, Akdoğan ve Aydemir'in (2018: 307) pozitif psikolojik sermaye ve işe yabancılaşma ile ilgili yaptıkları çalışma sonuçları ile örtüşmektedir. Buradan yola çıkarak öğretmenlerin öz yeterlilik algılarının yükseltilmesi ile davranış değişikliklerin ortaya çıkacağı ve yabancılaşmanın azalacağı sonucuna ulaşılmıştır. Bilgilerini ve becerilerini etkin bir şekilde kullanan, başarısızlığı kendine mal etmeyen, zorluklar ve stres karşısında mücadele edebilen, uyumlu, kendine güvenen ve öz saygısı yüksek öğretmenlerin yabancılaşmayı daha az yaşadıkları yorumu yapılabilir. Ayrıca bu çalışmada öğretmenin bireysel değer ve hedeflerinin, okulun değer ve hedefleriyle uyumlu olması ile yabancılaşmanın azalacağ sonucuna ulaşılmıştır. Birey-örgüt uyumunun artırılması ile öğretmenin okula olan bağl1lı̆̆ının, iş performansının ve iyi oluşunun artacağı yorumu yapılabilir.

Genel olarak, bu araştırmada birey örgüt uyumu aracı değişkeninin pozitif psikolojik sermaye ile örgütsel yabancılaşma ilişkisinde aracılık etkisine sahip olduğu istatistiksel olarak ortaya konmuştur. Pozitif psikolojik sermaye algısı ile örgütsel yabancılaşma arasındaki negatif yönlü ilişki öğretmenlerin örgüte uyumlu oldukları algısı ile pekişmektedir. Diğer bir ifade ile birey örgüt uyumun yüksek olduğu okullarda 
örgütsel yabancılaşma daha düşük olmaktadır. Bu bulgu Arslan, Güripek ve İnce'nin (2018: 2) yabancılaşma ve birey-örgüt uyumuna ilişkin yaptıkları çalışmanın sonuçlarıyla örtüşmektedir.

\section{SINIRLILIKLAR VE ÖNERILER}

Öğretmenlerin psikolojik sermaye algıları arasında en düşük katılım puanı alan boyut iyimserliktir. Bu alg1 birçok sebepten kaynaklı olabilir. Ancak eğitim sistemindeki sorunlara yönelik iyileşmelere gidilmesi, iyimser düşünme biçimini geliştirecektir. Bilimin rehberliğinde kaliteli bir eğitim sisteminin oluşturulması, iyimser düşünme biçimini de beraberinde getirecektir. Okulun tüm paydaşlarından oluşan okul danışma kurulu oluşturularak, okulun etkililiğini ve verimliliğini geliştirecek girişimlerde bulunulabilir. Bu kurul ile hem bireysel hem de örgütsel anlamda ihtiyaçlar belirlenerek ve karşılanarak öğretmenlerin okula uyum düzeyleri arttırılabilir. Öğretmenler ve okul yöneticilerinden oluşan yönetim kurulunun oluşturulması öğretmenlerin güçsüzlük hissini azaltabilir. Ayrıca öğretim programları ve modelleri, öğretmenin ve öğrencinin özerkliğini destekleyecek ve ihtiyaçlara göre esneklik sağlayabilecek bir biçimde tasarlanması, öğretmenin yabancılaşma sorununu ortadan kaldırabilir.

Birey-örgüt uyumunun öğretmenlerin olumsuz davranışsal çıktıları azaltması yönündeki araştırma bulgusuna binaen, bundan sonraki çalşsmalarda birey örgüt uyumun daha fazla incelenmesi önemli bulgular elde edilmesini sağlayabilir. Her çalışmanın olduğu gibi bu çalışmanın da bazı sınırılıkları bulunmaktadır. $\mathrm{Bu}$ araştırma sadece devlet okullarında görev yapan öğretmenlerin katılımı ile araştırma kapsamında kullanılan ölçeklerle elde edilen verilerden oluşmaktadır. Aynı araştırma özel okullarda görev yapan öğretmenlerle de tekrarlanabilir. Araştırma nicel araştırma yöntemleri kullanılarak gerçekleştirilmiştir. Elde edilen bulgular, nitel araştırma tekniklerinden yararlanılarak derinlemesine incelenebilir. Araştırma modeline farklı değiş̧kenler eklenerek, örneğin lider-üye etkileşimi, örgütsel destek, örgütsel güven vb. yeni araştırmalar yapılabilir. 


\section{KAYNAKÇA}

Akdoğan, A. ve Aydemir, C. (2018). Pozitif psikolojik sermayenin işe yabancılaşma üzerindeki etkisi. Uluslararası İktisadi ve İdari İncelemeler Dergisi, (17. UİK özel say1s1), 307-318.

Arıkan, R. (2013). Araştırma yöntem ve teknikleri. Nobel Yayın Dağıtım, Ankara.

Arslan, E., Güripek, E. ve İnce, C. (2018). İșe yabancılaşma ve kişi-örgüt uyumu arasındaki ilişkide kariyer bağlılığının rolü: Otel işletmelerinde bir araştırma. Journal of Recreation And Tourism Research, 5(1), 1-12.

Ataş, Ö. ve Ayık, A. (2013). Öğretmen adaylarında okula yabancılaşma, Turkish Studies 8(8), 103-122.

Averbek, E. (2016). İlkokullarda görevli öğretmenlerin örgütsel yabancılaşma ile örgütsel vatandaşlık davranışları arasındaki ilişki (Yayımlanmamış yüksek lisans tezi). Dicle Üniversitesi, Ĕ̈itim Bilimleri Enstitüsü, Diyarbakır.

Baron, R. M. ve Kenny, D. A. (1986). The moderator-mediator variable distinction in social psychological research: Conceptual, strategic and statistical considerations. Journal of Personality and Social Psychology, 51(6), 1173-1182.

Bright, L. (2007). Does person-organization fit mediate relationship between public service motivation and the job performance of public employees. Review of Public Personnel Administration, 27(4), 361-379.

Büyükgöze, H. (2014). Lise öğretmenlerinin görüşlerine göre algılanan örgütsel destek ve psikolojik sermaye ilişkisi. Yayımlanmamış Yüksek Lisans Tezi, Hacettepe Üniversitesi Ĕgitim Bilimleri Enstitüsü, Ankara.

Büyüköztürk, Ş. (2017). Sosyal bilimler için veri analizi el kitabı. Pegema Yayıncılık, Ankara.

Cable, D. M. ve Edwards, J. R. (2004). Complementary and supplementary fit: A theoretical and empirical integration. Journal of Applied Psychology. 89(5), 822-834.

Carless, S. A. (2005). Person-job fit versus person-organization fit as predictors of organizational attraction and job acceptance intentions: A longitudinal study. Journal of Occupational and Organizational Psychology, 78, 411-429.

Chatman, J. A. (1989). Improving interactional organizational research: A model of personorganization fit. Academy of Management Review, 14(3), 333-349.

Christensen, L. B., Johnson, R. B. \& Turner, L.A. (2015). Araştırma yöntemleri, desen ve analiz (Çeviri editörü: Ahmet Aypay). Anı Yayıncılık, Ankara. 
Çetin, F., Şeşen, H. ve Basım, H. N. (2013). Örgütsel psikolojik sermayenin tükenmişlik sürecine etkileri: Kamu sektöründe bir araştırma. Anadolu Üniversitesi Sosyal Bilimler Dergisi, 13(3), 95-107.

Çimen, İ. (2015). Öğretmenlerin psikolojik sermaye algısına ilişkin faktörlerin incelenmesi (Yayımlanmamış Yüksek Lisans Tezi). Gaziantep Üniversitesi, Eğitim Bilimleri Enstitüsü, Gaziantep.

Elçi, M., Alpkan L. ve Çekmecelioğlu, G. H. (2008, Haziran). The influence of person organization fit on the employees' perception of organizational performance. 4th International Strategic Management Conference. Sarayevo, Bosnia-Herzegovnia.

Erbaş, E. (2018). Öğretmenlerin pozitif psikolojik sermaye düzeyleri ile öğrenen özerkliğini destekleme davranışları (Yayımlanmamış Yüksek Lisans Tezi). Abant İzzet Baysal Üniversitesi, Eğitim Bilimleri Enstitüsü, Bolu.

Erjem, Y. (2005). Eğitimde yabancılaşma olgusu ve öğretmen: Lise öğretmenleri üzerine sosyolojik bir araştırma. Türk Eğitim Bilimleri Dergisi, 3(4), 395-417.

Eryılmaz, A. (2010). Lise öğretmenlerinin örgütsel yabancılaşma düzeyi (Yayımlanmamış Yüksek Lisans Tezi) Hacettepe Üniversitesi, Sosyal Bilimler Enstitüsü, Ankara.

Fettahlığlu, T. (2006). Örgütlerde yabancılaşmanın yönetimi: Kahramanmaraş özel işletme ve kamu kuruluşlarında karşılaşıtırmalı bir araştırma (Yayımlanmamış yüksek lisans tezi). Kahramanmaraş Sütçü İmam Üniversitesi, Sosyal Bilimler Enstitüsü, Kahramanmaraş.

Hair, J. F., C. Black, W. C., Babin, B. J. ve Anderson, R. E. (2010). Multivariate data analysis. Prentice Hall, Englewood Cliffs. NJ.

Işkın, Y. (2015). Otantik liderlik anlayışının örgütsel bağlılık ve örgütsel yabancılaşmayla ilişkisi mobilya sektöründe karşılaştırmalı bir araştırma (Yayımlanmamış yüksek lisans tezi). Kafkas Üniversitesi, Sosyal Bilimler Enstitüsü, Kars.

Keleş, H. N. (2011). Pozitif psikolojik sermaye: tanımı, bileşenleri ve örgüt yönetimine etkileri. Organizasyon ve Yönetim Bilimleri Dergisi, 3 (2), 343-350.

Keser, S. (2013). İlköğretim okulu yöneticilerinin otantik liderlik ve psikolojik sermaye özelliklerinin karşılaştırılması (Yayımlanmamış yüksek lisans tezi). Ylldız Teknik Üniversitesi, İstanbul.

Kılıç, K. C. (2010) Bireysel ve örgütsel değerler arasındaki uyumun çalışanların iş davranışlarına etkileri üzerine ampirik bir çalışma, Ç. Ü. Sosyal Bilimler Enstitüsü Dergisi, 19(1), 20-35. 
Kristof, A. L. (1996). Person-organization fit: An integrative review of its conceptualizations, measurement, and implications. Personnel Psychology, 49(1), 1-49.

Kurtulmuş, M. ve Karabıyık, H. (2016). Algılanan örgütsel adaletin öğretmenlerin işe yabancılaşma düzeylerine etkisi. Bartın Üniversitesi Ĕ̆itim Fakültesi Dergisi, 5(2), 459-477.

Luthans, F. ve Yousseuf, C. M. (2004). Human, social, and now positive psychological capital management: Investing in people for competitive advantage. Organizational Dynamics, 33(2), 143-160.

Luthans, F., Avey, J. B., Avolio, B. J. ve Peterson, S. J. (2010). The Development and Resulting Performance Impact of Positive Psychological Capital. Human Resource Development Quarterly, 21 (1), 41-67.

Luthans, F., Avolio, B. J., Avey, J. B. ve Norman, S. M. (2007). Positive psychological capital: Measurement and relationship with performance and satisfaction. Personnel Psychology, 60, 541-572.

Luthans, F., Youssef, C. M. ve Avolio, B. J. (2006). Psychological capital: Developing the human competitive edge. Oxford: Oxford University Press.

Marx, K. (2013). Kapital (B. Parkan, Der.), (A. Bilgili, Çev.). İstanbul: Say Yayınları.

Mottaz, C. J. (1981). Some determinants of work alienation. The Sociological Quarterly, 22(4), 515-529.

Netemeyer, R. G., Boles, J. S., McKee, D. O. ve McMurrian, R. (1997). An investigation into the antecedents of organizational citizenship behaviors in a personal selling context. Journal of Marketing, 61(3), 85-98.

O’Donohue, W. ve Nelson, L. (2014). Alienation: An old concept with contemporary relevance for human resource management. International Journal of Organizational Analysis, 22(3), 301-316.

Özkalp, E. ve Kırel, Ç. (2001). Örgütsel davranış. Anadolu Üniversitesi Yayınları, Eskişehir.

Rajaeepour, S., Arbabisarjou, A., Zivarirahman, M. ve Shokouhi, S. (2012). Relationship between organizational structure and organizational alienation. Interdisciplinary Journal of Contemporary Research in Business, 3(12), 188-196.

Sandage, S. J. ve Hill P. C. (2001). The virtues of positive psychology: The rapprochement and challenges of the affirmative postmodern perspective. Journal for the Theory of Social Behavior, 31, 241-260. 
Sarros, J. C., Tanewski, G. A., Winter, R. P., Santora, J. C. ve Densten, I. L. (2002). Work alienation and organizational leadership. British Journal of Management, 13(4), 285304.

Seeman, M. (1983). Alienation motifs in contemporary theorizing: The hidden continuity of the classic themes. Social Psychological Quarterly, 46(3), 171-184.

Sığrı, Ü. ve Gürbüz, S. (2013). Örgütsel davranış. Beta Yayınevi, İstanbul.

Silah, M. (2005). Endüstride çalışma psikolojisi. Seçkin Yayıncılık, Ankara.

Silverthorne, C. (2004). The impact of organizational culture and person- organization fit on organizational commitment and job satisfaction in Taiwan. The Leadership \& Organization Development Journal, 25(7), 592-599.

Snyder, C. R. (1995). Conceptualizing, measuring and nurturing hope. Journal of Counseling \& Development, 73, 355-360.

Snyder, C. R. ve Lopez, S.J. (2002). Handbook of positive psychology. Oxford University Press, London.

Soysal, A. (1997). Örgütlerde yabancılaşmaya ilişkin teorik ve uygulamalı bir çalışma (Yayımlanmamış yüksek lisans tezi). Selçuk Üniversitesi Sosyal Bilimler Enstitüsü, Konya.

Sungur, O. (2016). Korelasyon analizi. (Ş. Kalaycı, Ed.), SPSS uygulamalı çok değişkenli istatistik teknikleri, içinde (116-127), Ankara: Asil Yayıncılı.

Şimşek, M. Ş., Çelik, A. ve Akgemci, T. (2016). Davranış bilimlerine giriş ve örgütlerde davranış. Eğitim Yayınevi, Konya.

Şişman, M. (2002). Örgütler ve kültürler. Ankara: Pegem A Yayıncılık.

Tösten, R. (2015). Öğretmenlerin pozitif psikolojik sermayelerine ilişkin algılarının incelenmesi (Yayımlanmamış Doktora Tezi) Gaziantep Üniversitesi, Eğitim Bilimleri Enstitüsü, Gaziantep.

Tösten, R. ve Özkan, H. (2014). Psikolojik sermaye ölçeği: Geçerlik güvenirlik çalışması. Erzurum Kültür Eğitim Vakfi Dergisi, 59(2014), 429-442.

Tribe, J. ve Mkono, M. (2017). Not such smart tourism? The concept of e-lineation. Annalise of Tourism Research, 66(2017), 105-115.

Tummers, L., Bekkers, V., Van Thiel, S. ve Steijn, B. (2015). The effects of work alienation and policy alienation on behavior of public employees. Administration \& Society, 47(5), 596-617. 
Ulutaş, M. (2010) Birey-örgüt uyumu kuramı ve dalaman havalimanı çalışanları üzerine bir alan araştırması (Yayımlanmamış doktora tezi). Selçuk Üniversitesi, Sosyal Bilimler Enstitüsü, Konya.

Usta, R. (2010). İçsel pazarlama ve hizmet kalitesi arasındaki ilişki üzerinde örgütsel bağlılık ve iş tatmininin arac1lık etkisi. Erciyes Üniversitesi İIBF Dergisi, (34), 241-263.

Üngüren, E. , Kaçmaz, Y. Y. ve Y1lmaz, Y. (2016). The influence of sociodemographic factors on organizational alienation of accommodation businesses employees. European Scientific Journal, 12(4), 1-18.

Ünsal, Y. (2018). Eğitim örgütlerinde sergilenen hizmetkâr liderlik rollerinin öğretmenlerin örgütsel yabancılaşmasına etkisi (Yayımlanmamış doktora tezi). Harran Üniversitesi, Sosyal Bilimler Enstitüsü. Şanlıurfa.

Yapıcı, M. (2004). Eğitim ve yabancılaşma. Uluslararası İnsan Bilimleri Dergisi, 1(1) 1-9.

Yıldırım, A. ve Şimşek, H. (2005). Sosyal bilimlerde nitel araştırma yöntemleri. (5.basım), Seçkin Yayınevi, Ankara.

Yılmaz, S. ve Sarpkaya, P. (2009). Eğitim örgütlerinde yabancılaşma ve yönetimi. Uluslararasi Insan Bilimleri Dergisi, 6(2) 314-333. 